\title{
Energy balance in cross-country skiers: a study using doubly labeled water
}

Citation for published version (APA):

Sjodin, A. M., Andersson, A. B., Hogberg, J., \& Westerterp, K. R. (1994). Energy balance in cross-country skiers: a study using doubly labeled water. Medicine and Science in Sports and Exercise, 26(6), 720-724. https://doi.org/10.1249/00005768-199406000-00011

Document status and date:

Published: 01/01/1994

DOI:

10.1249/00005768-199406000-00011

Document Version:

Publisher's PDF, also known as Version of record

Document license:

Taverne

Please check the document version of this publication:

- A submitted manuscript is the version of the article upon submission and before peer-review. There can be important differences between the submitted version and the official published version of record.

People interested in the research are advised to contact the author for the final version of the publication, or visit the DOI to the publisher's website.

- The final author version and the galley proof are versions of the publication after peer review.

- The final published version features the final layout of the paper including the volume, issue and page numbers.

Link to publication

\footnotetext{
General rights rights.

- You may freely distribute the URL identifying the publication in the public portal. please follow below link for the End User Agreement:

www.umlib.nl/taverne-license

Take down policy

If you believe that this document breaches copyright please contact us at:

repository@maastrichtuniversity.nl

providing details and we will investigate your claim.
}

Copyright and moral rights for the publications made accessible in the public portal are retained by the authors and/or other copyright owners and it is a condition of accessing publications that users recognise and abide by the legal requirements associated with these

- Users may download and print one copy of any publication from the public portal for the purpose of private study or research.

- You may not further distribute the material or use it for any profit-making activity or commercial gain

If the publication is distributed under the terms of Article $25 \mathrm{fa}$ of the Dutch Copyright Act, indicated by the "Taverne" license above, 


\title{
Energy balance in cross-country skiers: a study using doubly labeled water
}

\author{
ANDERS M. SJÖDIN, AGNETA B. ANDERSSON, \\ JEANETTE M. HÖGBERG, and KLAAS R. WESTERTERP \\ PhysTest Scandinavia $A B$, and \\ Department of Nutrition, \\ University of Uppsala, \\ Uppsala, SWEDEN; and \\ Department of Human Biology, \\ University of Limburg, \\ Maastricht, THE NETHERLANDS
}

\begin{abstract}
SJÖDIN, A. M., A. B. ANDERSSON, J. M. HÖGBERG, and K. R. WESTERTERP. Energy balance in cross-country skicrs: a study using doubly labeled water. Med. Sci. Sports Exerc. Vol. 26, No. 6, pp. 720-724, 1994. Energy intake covering energy expenditure is essential for performance as well as for health aspects in endurance athletes. This study was performed to determine the energy needs for elite cross country skiers during a week of training and to demonstrate whether energy balance could be maintained. Energy intake was calculated from weighed dietary records and doubly labeled water was used to simultaneously measure energy turnover. Average daily energy intake ranged from 15.7 to $20.4 \mathrm{MJ} \cdot \mathrm{d}^{-1}$ in the females and from 25.7 to 36.0 $\mathrm{MJ} \cdot \mathrm{d}^{-1}$ in the males. This correlated well with the data for average daily energy turnover $(\mathrm{r}=0.96 ; P=0.0001)$ that ranged from 15.1 to $20.2 \mathrm{MJ} \cdot \mathrm{d}^{-1}$ and from 25.4 to $34.9 \mathrm{MJ} \cdot \mathrm{d}^{-1}$, in females and males, respectively. The mean difference being $0.1( \pm 1.9) \mathrm{MJ} \cdot \mathrm{d}^{-1}$. The close match between energy intake and energy expenditure has not previously been shown in athletes at these high levels of energy turnover. However, if energy intake over separate $24-h$ periods was compared with corresponding data for training, no significant relationship was found. This indicates that the athletes were not in energy balance during shorter periods. Furthermore, the validity of theoretical calculations of energy turnover, in highly trained subjects, derived from multiples of estimated BMR, is questioned.
\end{abstract}

ENERGY INTAKE, ENERGY TURNOVER, ENERGY REQUIREMENT, FOOD INTAKE, DOUBLY LABELED WATER, WEIGHED FOOD RECORDS, DIETARY RECORDS, ENDURANCE ATHLETES

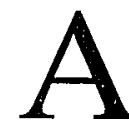
sufficient energy intake (EI) to balance the high energy turnover (ET) in endurance athletes during competition as well as training has been shown to be of great importance for performance (6). Furthermore, there is increasing evidence that a negative energy balance may have several adverse effects on

$01195-9131 / 94 / 2606-10720 \$ 3.00 / 0$

MEDICINE AND SCIENCE IN SPORTS AND EXERCISE

Copyright $(1994$ by the American College of Sports Medieine

Submitted for publication September 1993

Accepted for publication November 1993. health, e.g., on the immune system (9) as well as on sex hormones and bone mineralization $(7,11,21)$.

So far, few methods are available to quantify the energy requirement for subjects engaged in various athletic activities, without interfering with these activities. Laboratory experiments, using advanced technology such as a respiration chamber or a calorimeter suit, can have excellent accuracy but questionable relevance for the athlete under normal training situations. The alternative has often been field studies using indirect methods based on reported food intake, weight stability, and activity records. These methods are not optimal according to present standards (33) stating that recommendations for EI should, when possible, not be based on recorded EI but actual measurements of ET.

The aim of this field study was to determine the energy needs for skiers during normal training and to demonstrate whether energy balance could be maintained by measuring simultaneously ET and EI in a group of elite cross-country skiers, using the doubly labeled water technique and weighed food records, during a period with a typical training program. Previous field studies in physically active subjects have indicated energy balance by weight stability despite significant discrepancies between measured ET and reported EI $(17,28,30)$.

The study was performed after acceptance from the Ethical Committee of the Faculty of Medicine, University of Uppsala. Written informed consent was obtained from the subjects.

\section{SUBJECTS AND METHODS}

Four females and four males, from the Swedish national teams (Table 1), volunteered for the study. The study was performed during a preseason training camp, in the later part of October, with normal training volume 
TABLE 1. Antropometric data, BMR (calculated according to WHO/FAO/UNU 1985) and average daily training time for females (F1-F4) and males (M1-M4) as well as mean values and standard deviations for the two groups.

\begin{tabular}{|c|c|c|c|c|c|c|}
\hline Subject & $\begin{array}{l}\text { Age } \\
\text { (yr) }\end{array}$ & $\begin{array}{l}\text { Height } \\
\text { (cm) }\end{array}$ & $\begin{array}{c}\text { Weight } \\
\text { (kg) }\end{array}$ & $\begin{array}{l}\text { FFM } \\
(\mathrm{kg})\end{array}$ & $\begin{array}{c}\text { BMR } \\
\left(M J \cdot d^{-1}\right)\end{array}$ & $\begin{array}{l}\text { Training } \\
\left(\text { min } \cdot d^{-1}\right)\end{array}$ \\
\hline $\mathrm{F} 1$ & 28 & 164 & 52.5 & 42.6 & 5.4 & 147 \\
\hline $\mathrm{F} 2$ & 23 & 164 & 48.2 & 42.0 & 5.1 & 167 \\
\hline F3 & 25 & 168 & 59.2 & 48.2 & 5.8 & 182 \\
\hline $\mathrm{F} 4$ & 24 & 166 & 57.8 & 46.8 & 5.7 & 182 \\
\hline Mean & 25 & 166 & 54.4 & 44.9 & 5.5 & 170 \\
\hline $\mathrm{SD}$ & 2 & 2 & 5.1 & 3.1 & 0.3 & 17 \\
\hline$M 1$ & 28 & 174 & 70.0 & 62.3 & 7.3 & 208 \\
\hline M2 & 27 & 178 & 72.8 & 64.9 & 7.5 & 196 \\
\hline M3 & 24 & 188 & 81.5 & 72.3 & 8.0 & 210 \\
\hline M4 & 25 & 181 & 76.0 & 66.4 & 7.7 & 233 \\
\hline Mean & 26 & 180 & 75.1 & 66.5 & 7.6 & 212 \\
\hline SD & 2 & 6 & 4.9 & 4.2 & 0.3 & 16 \\
\hline
\end{tabular}

for this group at the time of the year. Females were observed for $7 \mathrm{~d}$ and males, arriving $1 \mathrm{~d}$ later in the camp, for $6 \mathrm{~d}$.

ET was measured using the doubly labeled water technique $(18,23)$. The subjects were given a weighed dose of a mixture of 99.8 atoms $\% 2 \mathrm{H}_{2} \mathrm{O}$ in 10.0 atoms $\% \mathrm{H} 218 \mathrm{O}$ so that baseline levels (ppm) were increased with 150 (SD 10) for $2 \mathrm{H}$ and 300 (SD 20) for 180. Urine samples were collected, for isotope measurement, before dosing at night and from the second voiding every morning thereafter. Isotope abundance in the urine samples was measured with an isotope-ratio mass spectrometer (Aqua Sira ${ }^{\circledR}$; VG Isogas) and $\mathrm{CO}_{2}$ production was calculated as previously described (29). All samples were measured in duplicate. $\mathrm{CO}_{2}$ production was converted to ET using an energy equivalent based on the individual food quotient (FQ) calculated (4) from the macronutrient composition of the diet according to the dietary records, and assuming $\mathrm{FQ}=\mathrm{RQ}$.

To assess the level of ET, ET was also expressed as a multiple of the Basal Metabolic Rate (BMR). BMR was calculated with the equations (WHO/FAO/UNU 1985):

$\operatorname{BMR}\left(\mathrm{kJ} \cdot \mathrm{d}^{-1}\right)=55.6 \cdot$ weight $(\mathrm{kg})$

$$
+1397.4 \cdot \text { height }(\mathrm{m})+146 \text { (females) }
$$

$\operatorname{BMR}\left(\mathrm{kJ} \cdot \mathrm{d}^{-1}\right)=64.4 \cdot$ wcight $(\mathrm{kg})$

$$
-113 \cdot \text { height }(\mathrm{m})+3000 \text { (males) }
$$

EI was calculated from weighed dietary records. Females recorded food intake during the first $5 \mathrm{~d}$ of the 7-d observation period and the males for $4 \mathrm{~d}$ of the $6 \mathrm{~d}$ of ET measurement. The subjects were carefully instructed and assisted by two dietitians at all meals, separately weighing all food items consumed. At the same time in between meal consumption of snacks and sport drinks was recorded. From these dietary records EI as well as the energy contribution from the different macronutrients were calculated by means of a computerized nutrient calculation system using the Swedish nutrient data base (National Food Administration, PC-Diet 1988).
Nude body mass was measured every morning, after overnight fasting and voiding, with a digital balance (EKS Electronic 0-120 $\pm 0.1 \mathrm{~kg}$ ). Body water was measured, once at the start of the observation period, by means of isotope dilution. Total body water was calculated according to the formula (25):

$$
[(2 \mathrm{H} \text { dilution space/1.04) }+(180 \text { dilution space/1.01) }] / 2 \text {. }
$$

Fat free mass (FFM) was calculated from body mass and total body water assuming a hydration coefficient of the FFM of 0.73 (19). Training records were used to assess the physical activity of the subjects.

Statistical calculations were performed using a PC program (STATGRAPHICS, Statistical Graphics System Ver. 5.0). Results are shown as means \pm 1 SD if not otherwise stated.

\section{RESULTS}

ET of the subjects during the observation period ranged from $15.1 \mathrm{MJ} \cdot \mathrm{d}^{-1}$ to $34.9 \mathrm{MJ} \cdot \mathrm{d}^{-1}$ reflecting differences in subject characteristics as well as different training schedules (Table 2).

\begin{tabular}{cccccc} 
TABLLE 2. Energy balance. & \multicolumn{5}{l}{} \\
\hline Subject & $\begin{array}{c}\Delta \text { Weight } \\
(\mathrm{kg})\end{array}$ & $\begin{array}{c}\mathrm{EI} \\
\left(\mathrm{MJ} \cdot \mathrm{d}^{-1}\right)\end{array}$ & $\begin{array}{c}\mathrm{ET} \\
\left(\mathrm{MJ} \cdot \mathrm{d}^{-1}\right)\end{array}$ & $\begin{array}{c}\text { ET } \\
(\text { METs })\end{array}$ & $\begin{array}{c}\text { E-balance } \\
(\%)\end{array}$ \\
\hline F1 & +0.4 & 18.2 & 19.4 & 3.6 & -6.2 \\
F2 & -0.1 & 18.7 & 15.1 & 3.0 & +19.2 \\
F3 & -0.2 & 20.4 & 20.2 & 3.5 & +1.0 \\
F4 & -0.4 & 15.7 & 18.6 & 3.3 & -18.4 \\
& & & & & \\
Mean & -0.2 & 18.2 & 18.3 & 3.4 & -1.1 \\
SD & 0.3 & 1.9 & 2.2 & 0.3 & 15.7 \\
& & & & & \\
M1 & -0.4 & 27.4 & 28.6 & 3.9 & -4.4 \\
M2 & +0.4 & 25.7 & 25.4 & 3.4 & +1.1 \\
M3 & +0.7 & 31.6 & 32.2 & 4.0 & -1.9 \\
M4 & +0.9 & 36.0 & 34.9 & 4.5 & +3.0 \\
& & & & & \\
Mean & +0.4 & 30.2 & 30.2 & 4.0 & -0.6 \\
SD & 0.6 & 4.6 & 4.2 & 0.5 & 3.3 \\
\hline
\end{tabular}

Body weight change over the observed period. Average daily energy intake (EI) and average daily energy turnover (ET) in $M J \cdot d^{-1}$ as well as multiples of BMR (METs) and the resulting energy balance (E-balance $=E I-E T$ in percent of $E T)$. 
The mean ET and EI for females were $18.3 \pm 2.2$ $\mathrm{MJ} \cdot \mathrm{d}^{-1}$ and $18.2 \pm 1.9 \mathrm{MJ} \cdot \mathrm{d}^{-1}$, respectively. The corresponding values for males were $30.3 \pm 4.2 \mathrm{MJ} \cdot \mathrm{d}^{-1}$ and $30.2 \pm 4.6 \mathrm{MJ} \cdot \mathrm{d}^{-1}$. The mean difference between ET and EI, for the entire group, being $0.1 \pm 1.9 \mathrm{MJ} \cdot \mathrm{d}^{-1}$. Furthermore, there was a very high correlation $(\mathrm{r}=0.96 ; P=$ 0.0001 ) between ET and EI as illustrated in Figure 1.

The daily variation in training time was greater than the variation in EI (Fig. 2). No significant correlation between training time and EI over the corresponding 24-h periods was found. Even if EI was expressed as multiples of BMR, in an attempt to reduce the effect of differences in subject characteristics (Fig. 2), no significant correlation $(P=0.07)$ was found.

Body mass did not change significantly $(+0.2 \pm 0.5$ $\mathrm{kg}$ ) during the observation period. The dietary record showed a mean energy contribution, to the total energy intake, of $13 \%$ from protein, $28 \%$ from fat, and $58 \%$ from carbohydrates, which is in accordance with dietary guidelines for optimal food intake in the population at large as well as for endurance athletes (16). The food quotient (FQ) calculated was $0.88 \pm 0.008 ; 16 \%$ of EI and $25 \%$ of the carbohydrates consumed came from various types of sport drinks.

\section{DISCUSSION}

The doubly labeled water technique used in this study has been shown to be both practical and valid to determine ET in humans under normal living conditions $(10,23,26)$ as well as during periods of intense physical activity (27). The estimation of EI using dietary records is, however, associated with a number of methodological problems. Registration periods of $7 \mathrm{~d}$ are often recommended to minimize the effect of day-to-day variations as well as tendencies to adapt the food intake in order to

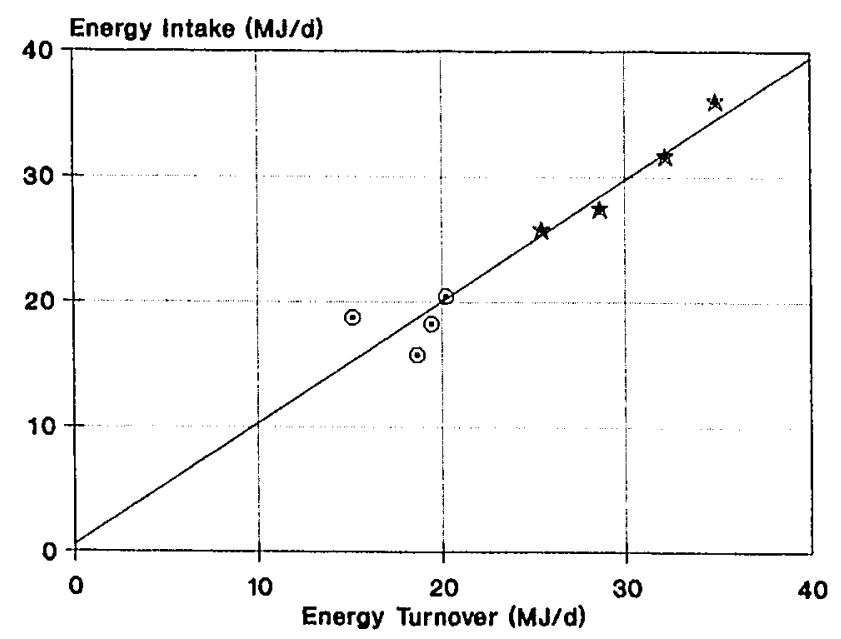

Figure 1-The relationship between energy turnover (E'T) and energy intake (EI) (dotted circles, females; stars, males). The equation for the fitted line was $y=1.2+0.95 x(r=0.96, p=0.0001)$.

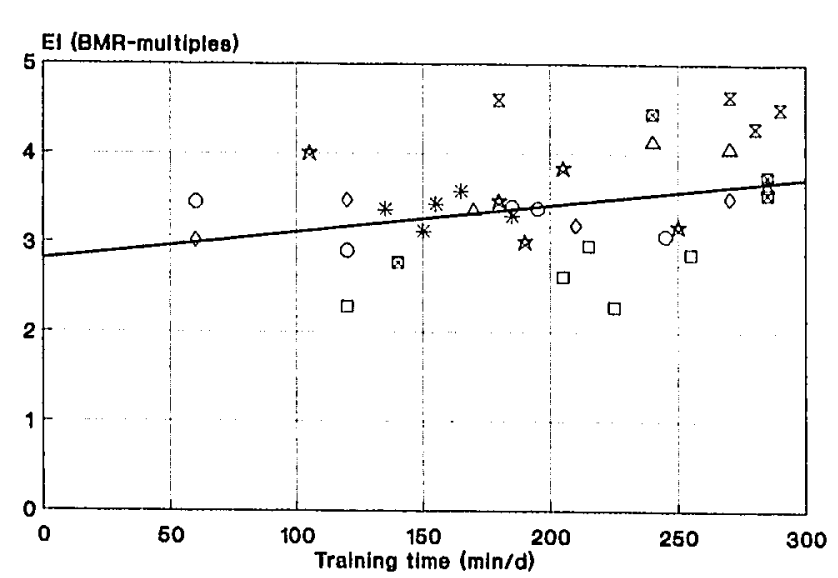

Figure 2-Reported energy intake over $24-h$ periods plotted against training time for the corresponding 24 h for each subject $(r=0.36, p$ $=0.07$ ).

make the registration easier or to be a "good subject" $(3,8,15)$. Own unpublished data from food records of skiers in a similar situation, however, indicate that food intake is not influenced by the day of the week, etc., to any great extent during an intensive training period. Therefore, we chose only to register food intake during 4-5 d in order to favor good compliance to accurately weigh and record the amounts of food and drinks consumed and to reduce the extra work for the subjects. We also believe that a high motivation in this group to constantly select food in order to optimize performance minimizes the risk that the registration itself may influence food intake.

Several authors have shown that energy balance is essential even during short periods in order to maintain optimal performance (22). Surprisingly, there was no significant correlation between EI and training time, on a daily basis, seen in our study. This may indicate practical problems to consume more energy with the present food regime used by this group. Over a longer period of time (6-7 d), however, energy balance was achieved by, deliberately or not, reducing the time of training to compensate for previous days in negative energy balance and not by a delayed increase in EI as described in the literature (12).

The relevance of correlating training time and $\mathrm{EI}$ on a 24-h basis, as a crude reflection of energy balance, can of course be questioned since intensity and thereby the energy cost of training may vary from day to day. Calculation of ET on a daily basis, by means of doubly labeled water, is unfortunately not possible, with the present technique, due to the biological half-life of the isotopes involved. Previous recordings of heart rate in this group of athletes (not published) show small day-to-day variations within subjects during this type of endurance training. Despite expected interindividual differences we believe that this comparison can be useful as an indication 
of the daily energy balance. Especially if we compare differences, within each subject, in training time $\cdot \mathrm{d}^{-1}$ with the corresponding data for EI (Fig. 2), we see a clear discrepancy indicating energy imbalance.

There is a limited amount of data in the literature regarding energy requirements, based on actual measurements of ET in subjects engaged in endurance training. Data on energy requirements based on reported food intake are more frequently published. Fogelholm (13) presented a review of reported dietary intakes of athletes, using various types of questionnaires, during normal endurance training. From these data (52 studies, published between 1982 and 1992) calculated weighed mean EI was 9.8 (range 6.7-19.2) $\mathrm{MJ} \cdot \mathrm{d}^{-1}$ for female endurance athletes and 16.8 (range 10.3-24.8) for males. However, the term "normal endurance training," included various training routines as well as individual and possible seasonal differences which may influence ET.

In addition it seems natural to question the validity of using recorded food intake to determine energy needs. Underestimations of EI up to 35\% have been reported $(17,24,31)$ when EI, based on recorded food intake, is compared with measured ET using the doubly labeled water technique. This is, however, in contrast to the high correlation between ET and EI found in this study. A possible explanation may be found in differences in methodology to obtain data to determine EI as well as the group and the situation studied.

In an attempt to determine the energy demands of elite cross-country skiing and how this was covered in their diet, Fogelholm et al. (14) studied energy needs as well as EI in a group of Finnish elite cross-country skiers during different periods of the year. To estimate ET, they used a method based on calculated BMR times 1.5 for ET during the nonexercising periods and activity factors, as described by Wilson et al. (32), to predict the energy cost during exercise. Using this method Fogelholm found that the energy needs of cross-country skiers in November was around $13 \mathrm{MJ} \cdot \mathrm{d}^{-1}$ for the females and $18 \mathrm{MJ} \cdot \mathrm{d}^{-1}$ for males. The corresponding values of EI found in this study were $14 \mathrm{MJ} \cdot \mathrm{d}^{-1}$ and $19 \mathrm{MJ} \cdot \mathrm{d}^{-1}$, respectively. If we apply this method to the subjects in our study we find measured ET to be $39 \%$ higher than the calculated value for ET. This indicates that the factors used to calculate ET, from BMR, during sedentary conditions and/or activity may not be valid for these subjects. If the factor for sedentary life, 1.5 , is thought to be valid the activity factor should be 15 instead of the proposed 10 . The factor we found is more in line with recently published factors for classification of energy cost during racing or maximal uphill skiing (1) and not moderate endurance training as in the present study. On the other hand, if we believe in the factors used for calculating ET during training the factor by which BMR should be multiplied to get an estimate of the energy cost of sedentary life would be 2.7 in average instead of the proposed 1.5. It can further be questioned whether BMR, calculated according to WHO/FAO/UNU (1985), is valid for these highly active subjects since RMR has been reported to be elevated after intense physical activity $(2,5,20)$. It makes the previously used activity factors questionable, at least in special groups like elite endurance athletes with extremely high metabolic capacities and a training that will highly influence the metabolic rate at a given experienced intensity and calls for further validation before they are used to assess energy needs in these subjects.

Only a few comparable studies of ET in elite endurance athletes based on actual measurements of energy turnover are found in the literature. Using the doubly labeled water technique, Haggarty et al. (17) reported a mean ET of 14.6 (SEM 0.63) $\mathrm{MJ} \cdot \mathrm{d}^{-1}$ and a corresponding EI of 9.7 (SEM 1.24) $\mathrm{MJ} \cdot \mathrm{d}^{-1}$ for a group of female endurance athletes registered during a 3-wk training period. This comparison between ET and EI implies a negative energy balance in the magnitude of $30 \%$. Westerterp et al. (30) showed levels of ET in four males during three different stages of a cycling race over $22 \mathrm{~d}$ (Tour de France) at $29.4 \mathrm{MJ} \cdot \mathrm{d}^{-1}, 36.0 \mathrm{MJ} \cdot \mathrm{d}^{-1}$, and $35.7 \mathrm{MJ} \cdot \mathrm{d}^{-1}$ with corresponding values for EI of $24.5 \mathrm{MJ}^{-1} \mathrm{~d}^{-1}, 26.3$ $\mathrm{MJ} \cdot \mathrm{d}^{-1}$, and $23.2 \mathrm{MJ} \cdot \mathrm{d}^{-1}$. This means a calculated negative energy balance of 13,21 , and $35 \%$ for the different stages of the race, despite weight stability over the periods studied. The same pattern was found in a group of 13 lean subjects $40 \mathrm{wk}$ after the start of an activity intervention study (28) where EI was found to be $19 \%$ lower than ET measured with doubly labeled water. Such discrepancies are of course not consistent with maintained energy stores in the body.

According to the data on ET and EI presented in this paper, our group of elite endurance athletes was in energy balance during a period of very high energy turnover. To our knowledge there is presently no other study in the literature, showing energy balance, based on simultaneously measured ET and EI, at these high levels of energy turnover. We believe that energy balance at these levels of physical activity can only be shown in a highly motivated group with an awareness of the importance of good nutrition, using suitable methods, such as doubly labeled water and supervised weighed dietary records over a limited observation period.

The authors wish to express their gratitude to the subjects for their dedicated participation and to Professor Leif Hambræus for his guidance and constructive criticism throughout the study.

This work was supported by Procordia AB and PhysTest Scandinavia $A B$.

Address for correspondence: Anders Sjödin, Dag Hammarskjöldsväg 21, S-752 37, Uppsala, Sweden. 


\section{REFERENCES}

1. Ainsworth, B. E., W. L. Haskel, A. S. Leon, et al. Compendium of physical activities: classification of energy costs of human physical activitics. Med. Sci. Sports Exerc. 25:71-80, 1993.

2. Bahr, R., I. Ingenes, O. VaAge, O. M. Sejersted, and E. A. NewSHOLM. Effect of duration on excess postexercise $\mathrm{O}_{2}$ consumption. J. Appl. Physiol. 62:485-490, 1987.

3. BINGHAM, S. A. Limitations of the various methods for collecting dictary intake data. Amm. Nutr: Metab. 35:117-127, 1991.

4. Black, E. A., A. M. Prentice, and W. A. Coward. Use of food quotients to predict respiratory quotients for the doubly-labeled water method of measuring energy expenditure. Hum. Nutr. Clin Nutr. 40C:381-391, 1986

5. Broeder, C. E., K. A. Burrus, L. S. SvaneviK, and J. H. WilMORE. The effects of either high intensity resistance or endurance training on resting metabolic rate. Am. J. Clin. Nutr. 55:802-810, 1992.

6. Brouns, F., W. H. M. Saris, J. Stroecken, et al. Eating, drinking, and cycling. A controlled Tour de France simulation study. Part II. Effect of diet manipulation. Int. J. Sports Med. 10:S41-S48, 1989.

7. Calloway, C. W. Dietary effects on osteoporosis. JAMA 257: $1652,1987$.

8. Cameron, M. E. and W. A. van Staveren. Manial on Methodology for Food Consumption Studies. New York: Oxford University Press, 1988, pp. 53-106.

9. Chandra, R. K. 1990 McCollum award lecture. Nutrition and immunity: lessons from the past and new insights into the future. Am. J. Clin. Nutr: 53:1087-1101, 1991.

10. Coward, W. A. The doubly-labelled-water (2H218O) method: principles and practice. Proc. Nutr. Soc. 47:209-218, 1988.

11. DrinkWATER, B. L. Athletic amenorrhea: a review in exercise and health. American Academy of Physical Education Papers No. 17: 120-131, Human Kinetics Publishers, 1983.

12. Edholm, O. G., J. G. Fletcher, E. M. Widdowson, and R. A. MCCANCE. The energy expenditure and food intake of individual men. Br. J. Nutr. 9:286-300, 1955.

13. Fogelholm, M. Vitamin and mineral status in physically active people. Dietary intake and blood chemistry in athletes and young adults. Publications of the Social Insurance Institution, Finland, ML:118. Turku, 1992, pp. 219-224.

14. Fogelholm, M., S. Rehunen, C.-G. GreF, et al. Dietary intake and thiamin, iron, and zinc status in elite Nordic skiers during different training periods. Int. J. Sport Nutr. 2:351-365, 1992.

15. Gibson, R. S. Principles of Nutritional Assessment. New York: Oxford University Press, 1990, pp. 97-116.

16. Grandjean, A. C. Macronutrient intake of US athletes compared with the general population and recommendations made for athletes. Am. J. Clin. Nutr. 49:1070-1076, 1989.

17. Haggarty, P., B. A. McGaw, R. J. Maughan, and C. Fenn. Energy expenditure of elite female athletes measured by the doubly-labelled water method. Proc. Nutr. Soc. 47:35A, 1988.

18. LifSON, N. and R. MCCLINTOCK. Theory and use of the turnover rates of body water for measuring energy and material balance. $J$. Theor: Biol. 12:46-74, 1966.

19. PACE, N. and E. N. Rothburn. Studies on body composition. III. The body water and chemically combined nitrogen content in relation to fat content. J. Biol. Chem. 158:685-691, 1945.

20. Poelman, E. T. and E. S. Horton. The impact of food intake and exercise on energy expenditure. Nutr: Rev. 47:129-137, 1989.

21. SANTORA, A. C. Rolc of nutrition and exercise in osteoporosis. Am. J. Med. 82(Suppl. 1B):73-79, 1987.

22. Saris, W. H. M., M. A. van Erp-BAart, F. Brouns, K. R. WesTERTERP, and F. TEN Hoor. Study on food intake and energy cxpenditure during extreme sustained excrcise: the Tour de France. Int. J. Sports Med. 10:S26-S31, 1989.

23. SCHOEller, D. A. Measurement of energy expenditure in freeliving humans by using doubly labeled water. $J$. Nutr. 118:1278$1289,1988$.

24. SCHOELlER, D. A. How accurate is self-reported dietary energy intake? Nutr: Rev. 48:373-379, 1990.

25. Schoeller, D. A., E. van Santen, D. W. Peterson, W. Dietz, J. JASPAN, and P. D. KLEIN. Total body water measurements in humans with $18 \mathrm{O}$ and $2 \mathrm{H}$ labeled water. Am. J. Clin. Nutr. 33:2686$2693,1980$.

26. Schoeller, D. A. and P. WebB. Five-day comparison of the doubly labeled water method with respiratory gas exchange. Am. $J$ Clin. Nutr. 40:153-158, 1984.

27. Westerterp, K. R., F. Brouns, W. H. M. Saris, and F. ten Hoor. Comparison of doubly labeled water with respirometry at low- and high-activity levels. J. Appl. Physiol. 65:53-56, 1988.

28. Westerterp, K. R., G. A. L. Meijer, E. M. E. Janssen, W. H. M. SARIS, and F. TEN HOOR. Long term effect of physical activity on energy balance and body composition. Br. J. Nutr. 68:21-30, 1992.

29. WesterterP, K. R. and W. H. M. Saris. Limits of energy turnover in relation to physical performance, achievement of energy balance on a daily basis. J. Sports Sci. 9:1-15, 1991.

30. Westerterp, K. R., W. H. M. Saris, M. VAN Es, and F. TEN Hoor. Use of the doubly labeled water technique in humans during heavy sustained exercise. J. Appl. Physiol. 61:2162-2167, 1986.

31. Westerterp, K. R., W. P. H. G. Verboeket-VAn dE Venne, G. A. L. MEIJER, and F. TEN Hoor. Self-reported intake as a measure for energy intake. A validation against doubly labelled water. In: Obesity in Europe 91, G. Ailhaud, B. Guy-Grand, M. Lafontan, et al. (Eds.). London: John Libbey \& Company Ltd. 1991, pp. 17-22.

32. Wilson, P. W. F., R. S. Paffendarger Jr., J. N. Morris, and R. J. HAVLIK. Assessment methods for physical activity and physical fitness in population studies: report of a NHLBI workshop. Am. Heart J. 111:1177-1192, 1986.

33. World Health Organization. Energy and Protein Requirements, Report of a Joint FAO/WHO/UNU Expert Consultation. Geneva: WHO, 1985, pp. 34-52 (Tech Rep Ser 724). 